\author{
Asian Journal of Economic Modelling \\ $\operatorname{ISSN}(e): \quad 2312-3656$ \\ $\operatorname{ISSN}(p): \quad 2313-2884$ \\ DOI: $10.18488 /$ journal.8.2021.92.145.152 \\ Vol. 9, No. 2, 14.5-152. \\ (C) 2021 AESS Publications. All Rights Reserved. \\ URL: www.aessweb.com
}

\title{
ADAPTING TO CLIMATE CHANGE IN VIETNAM: INSIGHTS FROM A STRUCTURAL MODEL
}

Amr Hosny

\author{
International Monetary Fund, Washington, DC, USA. \\ Email:ahosny@imf.org Tel: +1(202)623-4472
}

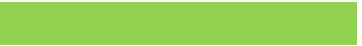

Article History

Received: 25 January 202 Revised: 2 March 2021 Accepted: 30 March 202 Published: 22 April 2021

\section{Keywords \\ Vietnam \\ Climate change \\ DSGE structural models \\ Resilient infrastructure \\ Climate change adaptation \\ Debt sustainability.}

\section{JEL Classification:}

E22; E62; F34; F35; H54; H63;

$\mathrm{H} 84 ; \mathrm{O} 23 ; \mathrm{Q} 54$.

\begin{abstract}
Vietnam is increasingly exposed to climate change. The COVID-19 crisis offers an opportunity to push for green investment and climate-resilient adaptation. In this context, the paper uses a DSGE structural model, calibrated to features of the Vietnamese economy, to simulate the macroeconomic trade-offs of investing in resilient infrastructure. Compared to scenarios of a baseline no policy change and additional standard infrastructure spending, the model findings illustrate the long-term benefits of adaptation infrastructure investments on growth and public debt dynamics. Specifically, while adaptation infrastructure is initially slightly costlier during the scale-up period, it can better withstand natural disaster shocks, and over time, would have lower maintenance costs and higher return than conventional infrastructure. Other model scenarios illustrate the trade-offs of different financing sources as well as the benefits of public financial management reforms that improve investment efficiency.
\end{abstract}

Contribution/ Originality: This paper contributes to the literature by using a DSGE structural model, calibrated to features of the Vietnamese economy, to simulate the macroeconomic trade-offs of investing in climateresilient infrastructure in Vietnam. Model findings illustrate the long-term benefits of adaptation infrastructure investments on growth and public debt dynamics.

\section{INTRODUCTION}

Vietnam is increasingly exposed to climate change. The country's geography, rising sea levels and temperatures make it one of the most vulnerable in the Asia-Pacific region (IMF, 2017; World Bank, 2010). A high proportion of the country's population and economic assets are located in coastal lowlands and deltas. Natural disasters, one manifestation of climate change, are increasing in frequency and impact threatening physical and human capital and growth.

A key challenge for Vietnam is to manage its rapid economic development in a sustainable manner. Vietnam's structural transformation, manifested through rapid industrialization and urbanization over recent decades has drastically improved its standard of living but at the same time has also increased the country's greenhouse gas (GHG) emissions and vulnerability to climate change. Reducing environmental degradation and improving resilience to climate change can have mutually reinforcing benefits if managed effectively (ADB, 2013).

Climate change impacts all sectors of the economy and threatens to stall or reverse progress on growth and poverty reduction. Climate change is one of the greatest challenges facing policymakers worldwide, and the stakes 
are particularly high for Asia and the Pacific (IMF, 2021). Beyond the short-term damage impacts of natural disasters, floods or storms, climate change as manifested in gradual temperature rises and rising sea levels can affect long-term growth potential and livelihoods in general. For example, Arndt, Tarp, and Thurlow (2015) estimate that climate change could reduce national income by up to 3.5 percent by 2050 in Vietnam.

Fiscal policy can play a critical role in responding to challenges posed by climate change. The literature has often distinguished between climate change mitigation versus adaptation. Mitigation refers to efforts to reduce or prevent emissions of greenhouse gases and focuses on fiscal issues related, for example, to tax policies (e.g. carbon pricing and redistribution of its revenues). Adaptation refers to efforts to adapt to the effects of climate change, especially relevant for countries vulnerable to rising seas and extreme weather events. It focuses on fiscal issues related, for instance, to public financial management (PFM) (e.g., emergency procedures, contingency funds) and government expenditure policies (e.g., social safety nets, health spending, resilient versus standard infrastructure). World Bank (2010); World Bank (2011) provided early assessments and action plans of such policies in Vietnam.

Vietnam is placing climate change at the core of its development agenda. The National Climate Change Strategy was issued in 2011, outlining the objectives for 2016-2050. In 2012, the National Green Growth Strategy was approved, which includes mitigation targets and measures. In 2013, the Law on Natural Disaster Prevention and Control was enacted, aiming to address diverse natural hazards that affect the country. Vietnam pledges within the Paris Agreement on Climate in 2016 commit to reducing GHG emissions by 8 percent compared to business as usual by 2030 (see IMF (2017)) and Escobar et al. (2019) for details).

The COVID-19 crisis offers an opportunity to push for green investment and climate-resilient adaptation. Vietnam has addressed climate challenges through a range of national policies and concrete adaptation measures, but there is scope to do more to both build economic and environmental resilience and foster the economic recovery. The government's own strategy for the 2021-2030 period recognizes that climate change adaptation must be linked to sustainable development and the transition towards a low-carbon economy. Understanding how greater adaption investment could impact growth and the tradeoffs involved with respect to other investments is important.

A number of papers have studied the role of public investment scaling-up in frontier Asian economies, including Vietnam. Ghazanchyan, Ricardo, Jiri, and Kaitlyn (2017) use a dynamic stochastic general equilibrium (DSGE) model to explore the macroeconomic impact of alternative public investment scaling-up strategies in three fast-growing Southeast Asian economies: Cambodia, Sri Lanka, and Vietnam. They show that a gradual public investment profile is more favorable than front-loading capital spending, and illustrate that improving the efficiency of revenue collection over time may ease the burden of fiscal adjustment, achieving better GDP and debt sustainability outcomes. Baum (2020) undertakes a forward-looking costing exercise and finds that achieving selected Sustainable Development Goals (SDGs) in Vietnam would require an additional 7 percent of GDP by 2030. Thanh and Dapice (2009) provided earlier estimates in this context as well highlighting that transport and electricity are sectors with the greatest needs for investments.

Studies on investing in climate change infrastructure are less common. In an application to Vanuatu and cyclone Pam, Marto, Papageorgiou, and Klyuev (2018) use a DSGE model to show that adaptative infrastructure can better withstand the impact of natural disasters, crowd in private investments and improve debt dynamics. Balboni (2019) uses a dynamic spatial equilibrium framework and detailed georeferenced data from Vietnam and finds evidence that focusing large infrastructure investments in coastal areas may have positive returns, but could be outperformed by allocations concentrated further inland. Regarding sector-specific studies, Nguyen, Renaud, Sebesvari, and Nguyen (2019) present options for the resilience of agricultural systems in Vietnam, while Arndt et al. (2015) study the impact of a full range of climate projections on multi-sectors including agriculture and roads.

The paper contributes to the literature by using a DSGE model to study the growth and debt dynamics of investing in adaptive infrastructure in Vietnam as a means of improving the country's resilience to climate change. Specifically, we use the DIGNAD model, developed by Marto et al. (2018) and Vietnam as a case study to illustrate 
the benefits of adaptation infrastructure investments on growth and public debt dynamics. This work contributes to the literature by applying a the DIGNAD model to Vietnam, one of the highest vulnerable countries in the world to climate change. A case study by IMF (2018) on Solomon Islands is the closest to our paper in terms of methodology and analysis. IMF (2021) and IMF (2020a) conduct a similar exercise for Asian and Sub-Sahran African regions.

This paper is structured as follows. After the introduction, section II presents some stylized facts, section III presents the model simulations and discusses its findings. Finally, section IV concludes.

\section{AN INITIAL LOOK AT THE DATA}

Vietnam is increasingly exposed to climate change. Global indices of vulnerability and readiness put Vietnam among the most exposed group of countries to climate change (Figure 1). The vulnerability index, measured by GERMANWATCH global climate risk index, analyzes to what extent countries have been affected by the impacts of weather-related loss events such as storms, floods and heat waves etc. It is an index of the number of fatalities, insured damages and total economic losses. ${ }^{1}$ The readiness index, measured by the Notre Dame Global Adaptation Initiative (ND-GAIN), summarizes a country's readiness and ability to leverage investments into adaptation actions. ${ }^{2}$ This for example captures the country's readiness in economic (such as business environment), governance (e.g. institutional factors) and social (e.g. education, ICT infrastructure) aspects that would enhance the application of investments for adaptation.

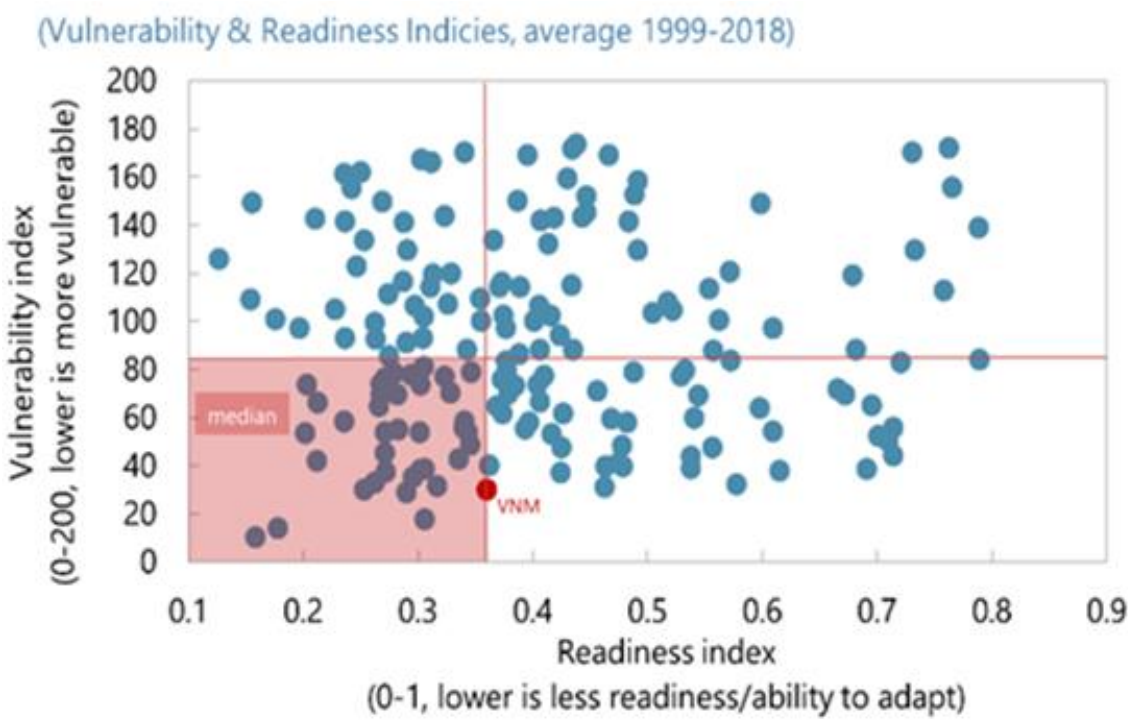

Figure-1. Exposure to Climate Change

Source: Global Climate risk index (vulnerability) and global adaptation index (readiness).

Note: (i) Global climate risk index, by GERMANWATCH, is based on fatalities and economic losses from weather-related events; (ii) Global adaptation index, by ND.GAIN, is based on the country's ability to leverage investments and convert them to adaptation actions.

A key element of effective climate change adaptation policies is to strengthen the resilience of physical assets. A recent study by IMF (2021) estimates the costs of both upgrading new projects, and retrofitting existing assets for a number of countries in the Asia-Pacific region (Figure 2). Upgrading new investment projects involves choices in the design and materials, for example, new roads could incorporate drainage to sustain heavier rainfall or be built on more-elevated terrain to reduce risk of flooding. Retrofitting existing assets involves modifying existing capital stock exposed to natural hazards, and as such is typically more expensive. The IMF (2021) estimates that retrofitting and upgrading investments in Vietnam could reach between 3-4 percent of GDP. Also see (IMF, 2019a) for additional details.

\footnotetext{
${ }^{1}$ Available at https://germanwatch.org/en/cri.

2 Available at https://gain.nd.edu/our-work/country-index/.
} 


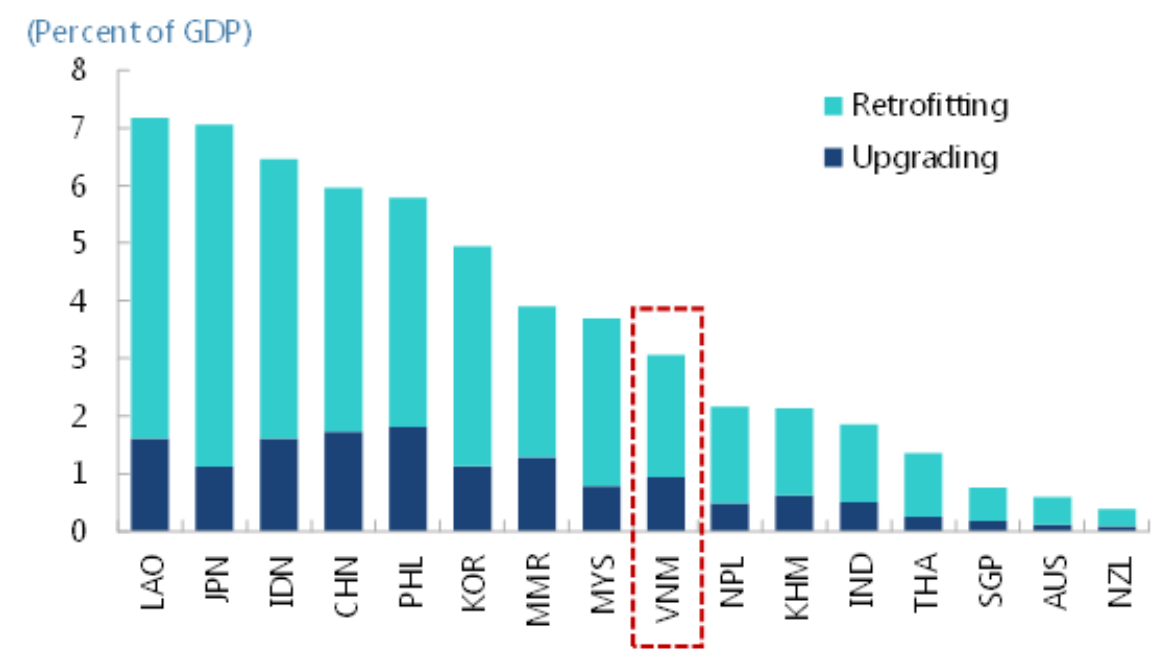

Figure-2. Annual cost of upgrading investments and retrofitting existing assets. Source: IMF (2021).

Climate change has had sizeable economic and environmental impacts on the region. Greater monsoon variability in South and Southeast Asia has led to more extreme rainfalls in some areas, while causing rainfall deficits and droughts in others. Relatedly, floods and droughts have increased significantly by 150 percent and 50 percent over the last four decades, respectively, in Asia and the Pacific (EM-DAT, 2020; IMF, 2021).

\section{SIMULATIONS AND FINDINGS}

Structural models can simulate the trade-offs of investing in resilient infrastructure. The Debt-InvestmentGrowth (DIG) model, introduced by Buffie, Andrew, Catherine, Rafael, and Luis-Felipe (2012) is a dynamic stochastic general equilibrium (DSGE) framework that simulates the macroeconomic effects of public investment scaling-ups via investment-growth linkages, financing options and public debt dynamics in a small open economy. Melina, Yang, and Zanna (2016) extended it to Natural Resource abundant countries (DIGNAR) by featuring a resource fund that can act as a fiscal buffer. Gurara, Giovanni, and Luis-Felipe (2019) provide a survey of applications and lessons from DIG and DIGNAR models. Marto et al. (2018) extended the framework to model the impact and channels of Natural Disasters (DIGNAD) including by allowing investments in both standard (e.g. roads) and adaptative/resilient (e.g. seawalls) infrastructure. All models of the DIG family incorporate household and firm heterogeneity with a rich government fiscal block that allows for various financing instruments.

The DIGNAD model simulates how a government can prepare for a natural disaster shock with alternative investment and financing strategies. Specifically, the Marto et al. (2018) DSGE model is a two-sector small open economy model featuring the impact of a natural disaster shock and how a government can prepare it using alternative investment strategies (standard versus adaptive infrastructure) and public financing strategies (domestic versus external borrowing, including the impact of grants and concessional sources, following Bevan and Adam (2016)). As argued in Marto et al. (2018) and IMF (2018) natural disasters can influence the economy through permanent damages to public and private infrastructure, temporary losses of productivity; and increased inefficiencies in public investment during the reconstruction process. ${ }^{3}$ Cantelmo, Leo, Giovanni, and Gonzalo (2019) extend Marto et al. (2018) framework to model natural disasters as continuous shocks rather than one-time events.

In this paper, we calibrate the DIGNAD model to features of the Vietnamese economy. The initial country specific parameters on public investments to GDP (5.9 percent), grants (0.1 percent), domestic debt (26 percent), external concessional (9 percent) and external commercial debt to GDP (9 percent), share of public debt adjustment between commercial external and domestic financing (75 percent domestic), imports to GDP (74 percent), trend per

${ }^{3}$ See the Marto et al. (2018) paper for details on model set-up, equations and calibration. 
capita growth (5.5 percent), and real interest rate on domestic and external commercial debt (1.5 and 1.0 percent respectively) are all taken from Vietnam's Debt Sustainability Analysis (DSA) (IMF, 2019b). We assume public investment efficiency of 77 percent following findings of IMF Public Investment Management Assessment (PIMA) reports and Ghazanchyan et al. (2017) for both the steady state and for additional investment during the initial investment surge, and that scaling up does not strain absorptive capacity.

Key assumptions: External concessional debt and grants are exogenous; while other sources of financing are allowed to be endogenous. Adaptation infrastructure spending is assumed at 10 percent of total government infrastructure expenditure (0.59 percent). Government revenues come from VAT (assumed at a flat 10 percent, consistent with prevailing VAT rates in Vietnam) and user fees for infrastructure services (5 percent of recurrent costs following Buffie et al. (2012)), and spending goes to transfers, debt service and (standard and adaptation) infrastructure investment. Fiscal adjustment by raising VAT is constrained. Capital's share in value added in tradable and non-tradable sectors are 40 and 55 percent respectively following Buffie et al. (2012). Financing in scenarios (ii) and (iii) are assumed to be covered fully by grants in year one, then by grants and concessional external debt in year two, then by domestic and external commercial debt as described by model parameters.

How does additional public investment affect growth? It depends on both the marginal product of effective public capital (which is a function of rates of return and depreciation) and public investment efficiency. Initial return on standard/adaptation investments is assumed at 15/40 percent respectively, while the depreciation rate of public standard/adaptation capital is assumed at 15/3 percent respectively, following IMF (2018).

Natural disaster shock: In all three scenarios (as explained below), we assume the country is hit by a natural disaster (in year six) after five years of scaling-up infrastructure spending (as in (IMF, 2018); IMF (2021)) and the shock lasts for three years. The shock increases the external debt risk premium by 15 percent (as in Marto et al. (2018)) and destroys 20 percent of both the tradable and non-tradable outputs. Adaptation capital is assumed to cushion the impact of natural disasters by a scaling parameter of 0.1 in both tradable and non-tradable sectors.

This paper assumes three different scenarios in the event of a natural disaster shock. The scenarios for illustrative purposes are: (i) a "baseline" no change scenario where public infrastructure is not increased beyond its initial starting point; (ii) a "standard" scenario with gradual ${ }^{4}$ scaling up of additional standard infrastructure of 0.2 percent of GDP a year for five years; and (iii) an "adaptation" scenario with similar gradual spending profile over five years, but 30 percent more expensive (an average of additional costs of upgrading and retrofitting adaptation projects which can be 15 and 50 percent more costly, respectively, as in IMF (2020b))..$^{5}$ Cantelmo et al. (2019) also assume that investing in resilient infrastructure is more expensive. The impact of additional investments on growth critically depends on both the marginal product of effective public capital and public investment efficiency.

The analysis suggests that investment in adaptation could yield significant growth and debt reduction benefits Figure 3. Adaptation infrastructure is initially slightly costlier during the scale-up period. This is reflected in a higher fiscal deficit during the initial five years. That said, its higher return, lower depreciation rate and ability to cushion the impact of natural disasters almost halves the jump in the fiscal deficit at the time of the shock (year six). Even in the absence natural disasters, the long-run average maintenance/repair costs of adaptative infrastructure are lower than conventional infrastructure. The now more resilient infrastructure under the adaptation scenario contribute to a lower GDP growth drop at the time of the assumed natural disaster shock. Additionally, investing in resilient infrastructure would raise the marginal product of productive capital, crowd in private investments, and contribute to a smaller drop in real GDP growth relative to other scenarios, both during and following the natural disaster shock (year six and beyond). The combined effect of lower fiscal deficits, lower new additional borrowing

\footnotetext{
${ }^{4}$ Ghazanchyan et al. (2017) using an extension of the Buffie et al. (2012) DIG model, present evidence that investing gradually is better for growth and debt dynamics in a sample of emerging and developing Asian countries.

${ }_{5}^{5}$ This amount of scaling-up is in line with Vietnam-specific adaptation cost estimates presented in IMF (2021).
} 
needs, and lower GDP drop at the time of the shock lead to lower public debt over time compared to standard investments, albeit still higher than the baseline of no (additional) investments.
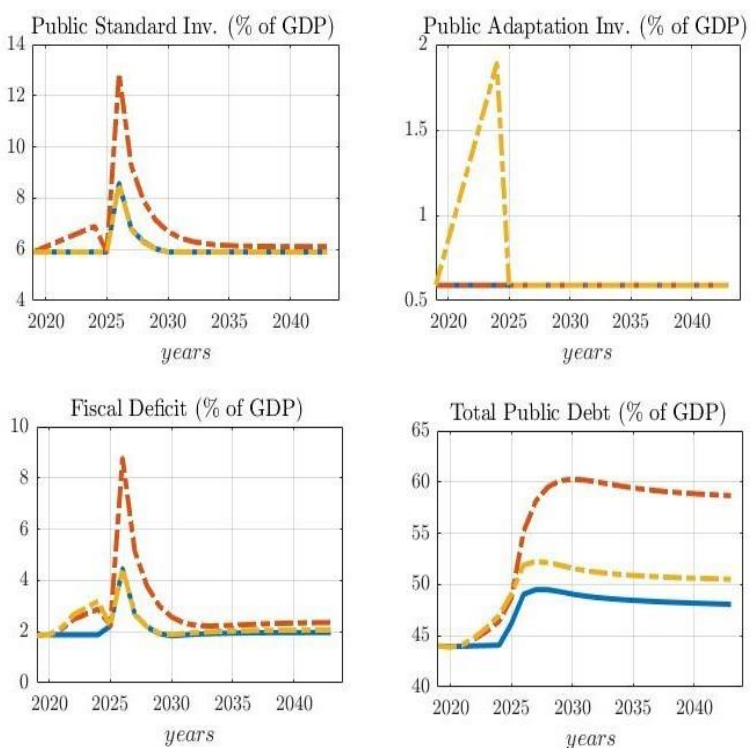

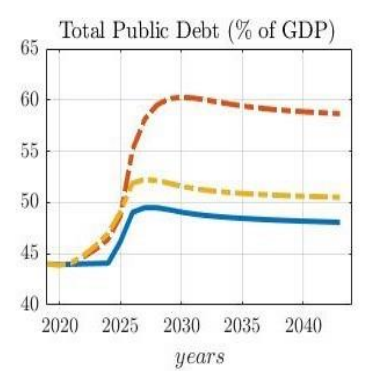

Figure-3. Simulated results under three scenarios.
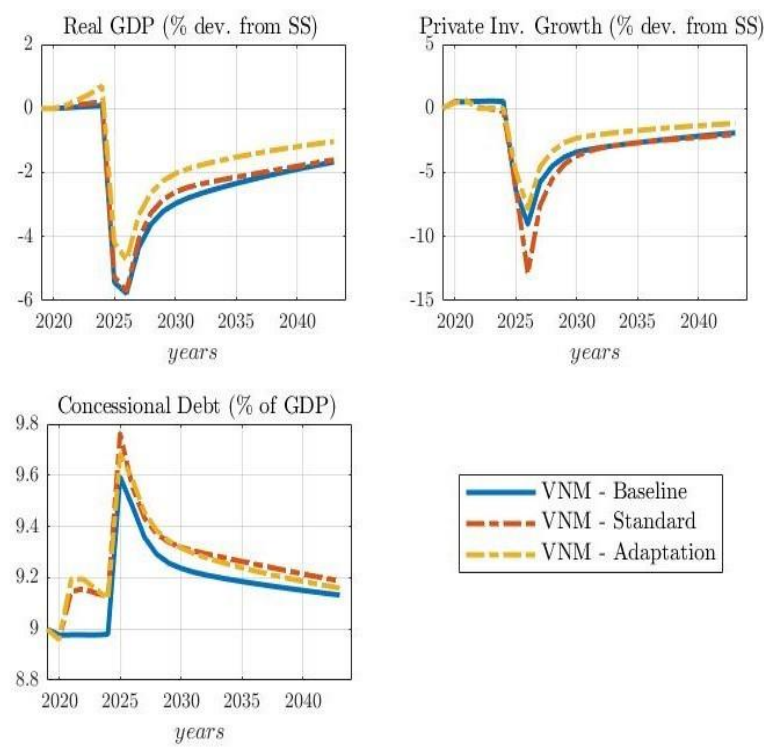

Other scenarios were also considered to highlight the role of PFM reforms and funding sources (not shown here). Public Financial Management (PFM) reforms are modeled as a higher return and efficiency of public investment. Similar results are reported in Cantelmo et al. (2019). The results suggest that gains to growth and debt dynamics increase gradually and are fully realized over time. A heavier reliance on domestic borrowing crowds-out the private sector, especially in the aftermath of the natural disaster shock. This results in lower real GDP growth over time, also given the more expensive debt service. Utilizing more grants to finance infrastructure, whether standard or adaptation, improves the growth and debt path, although Vietnam has historically low reliance on grants.

\section{CONCLUSION AND POLICY IMPLICATIONS}

Vietnam is increasingly exposed to climate change, and a key challenge is to manage its rapid economic development in a sustainable manner. Vietnam's structural transformation, manifested through rapid industrialization and urbanization over recent decades has drastically improved its standard of living but at the same time has also increased the country's greenhouse gas (GHG) emissions and vulnerability to climate change. The country's geography, long coastal lines, rising sea levels and temperatures make it one of the most vulnerable to climate change in the world. Natural disasters, one manifestation of climate change, are increasing in frequency and impact threatening physical and human capital and growth. Climate change impacts all sectors of the economy and threatens to stall or reverse progress on growth and poverty reduction. Improving resilience to climate change can have mutually reinforcing benefits if managed effectively.

In this context, the paper uses a DSGE model to study the growth and debt dynamics of investing in adaptive infrastructure in Vietnam. Specifically, we use the DIGNAD model, developed by Marto et al. (2018) and calibrate it to the features of Vietnam as a case study, to illustrate the benefits of investing in adaptative/resilient infrastructure versus standard investments, and simulate the impact on growth, deficits and public debt over the long-term.

The paper's main finding is that adaptation investment, albeit initially more costly, can cushion the impact of shocks, and improve growth and debt dynamics over the medium and long-term. Model simulations suggest that 
adaptation infrastructure is initially slightly costlier during the scale-up period, but its higher return, lower depreciation rate and ability to cushion the impact of natural disasters almost halves the jump in the fiscal deficit at the time of an illustrative natural disaster shock. This leads to lower public debt over time compared to standard investments. Private investments under the adaptation scenario with better efficiencies and return on capital also contribute to a smaller drop in real GDP growth relative to other scenarios.

Model-based findings suggest that spending reprioritization and efficiency can improve long-term macroeconomics outcomes. Re-orienting government expenditures towards climate resilient infrastructure, while initially imposing a higher fiscal burden, could help cushion the economy from natural disaster shocks, thus improving growth and public debt dynamics over the long-term. External concessional fuinaincg and/or grants would help cushion the initial fiscal burden of such investments. Additionally, timely PFM reforms in the specific area of strengthening public investment management, has the potential to boost gains from climate-resilient infrastructure investments.

Funding: This study received no specific financial support.

Competing Interests: The author declares that there are no conflicts of interests regarding the publication of this paper.

\section{REFERENCES}

ADB. (2013). Vietnam: Environment and climate change assessment. Mandaluyong City, Philippines: Asian Development Bank (ADB).

Arndt, C., Tarp, F., \& Thurlow, J. (2015). The economic costs of climate change: A multi-sector impact assessment for Vietnam. Sustainability, 7(4), 4131-4145. Available at: https://doi.org/10.3390/su7044131.

Balboni, C. A. (2019). In harm's way? Infrastructure investments and the persistence of coastal cities. Doctoral Dissertation, the London School of Economics and Political Science (LSE).

Baum, A. (2020). Vietnam's development success story and the unfinished SDG agenda. IMF Working Paper No. WP/20/31. Washington, DC: International Monetary Fund.

Bevan, D., \& Adam, C. (2016). Financing the reconstruction of public capital after a natural disaster. World Bank Policy Research Working Paper No. 7718. Washington DC: World Bank.

Buffie, E. E., Andrew, B., Catherine, P., Rafael, P., \& Luis-Felipe, Z. (2012). Public investment growth, and debt sustainability: Putting together the pieces. IMF Working Paper No. WP/12/144. Washington, DC: International Monetary Fund.

Cantelmo, A., Leo, B., Giovanni, M., \& Gonzalo, S. (2019). Policy trade-offs in building resilience to natural disasters: The case of St. Lucia. IMF Working Paper No. WP/19/54. Washington, DC: International Monetary Fund.

EM-DAT. (2020). The international disaster database. Center for research on the epidemiology of disasters. Retrieved from https://www.emdat.be/.

Escobar, C. D., Grosjean, G., Läderach, P., Nghia, T. D., Sander, B. O., McKinley, J., \& Tapasco, J. (2019). Reviewing Vietnam's nationally determined contribution: A new perspective using the marginal cost of abatement. Frontiers in Sustainable Food Systems, 3, 14. Available at: https://doi.org/10.3389/fsufs.2019.00014.

Ghazanchyan, M., Ricardo, M., Jiri, J., \& Kaitlyn, D. (2017). Collect more, spend better: Public investment in Asian frontier markets. IMF Working Paper No. WP/17/10. Washington, DC: International Monetary Fund.

Gurara, D., Giovanni, M., \& Luis-Felipe, Z. (2019). Some policy lessons from country applications of the DIG and DIGNAR models. IMF Working Paper No. WP/19/62. Washington, DC: International Monetary Fund.

IMF. (2017). Environment and climate change. Vietnam Selected Issues Paper, IMF CR 17/191. Washington, DC: International Monetary Fund.

IMF. (2018). Public investment in the face of natural disasters: A model application to Solomon Islands. Solomon Islands Selected Issues Paper, IMF CR 18/73. Washington, DC: International Monetary Fund. 
IMF. (2019a). Building resilience in developing countries vulnerable to large natural disasters. IMF Policy Paper No. 19/020, International Monetary Fund, Washington, DC.

IMF. (2019b). Vietnam : 2019 Article IV consultation; press release; staff report; and statement by the executive director for Vietnam. Washington, DC: International Monetary Fund.

IMF. (2020a). Adapting to climate change in Sub-Saharan Africa, Chapter 2 of the April 2020 Sub-Saharan Africa regional economic outlook. Washington, DC: International Monetary Fund.

IMF. (2020b). Investing in a sustainable, inclusive, and green recovery, Chapter 2 in fiscal monitor, October 2020. Washington, DC: International Monetary Fund.

IMF. (202 1). Fiscal policies to address climate change in Asia and the pacific: Opportunities and challenges. Departmental Paper No. 21/07. Washington, DC: International Monetary Fund.

Marto, R., Papageorgiou, C., \& Klyuev, V. (2018). Building resilience to natural disasters: An application to small developing states. Journal of Development Economics, 135, 574-586. Available at: https://doi.org/10.1016/j.jdeveco.2018.08.008.

Melina, G., Yang, S.-C. S., \& Zanna, L.-F. (2016). Debt sustainability, public investment, and natural resources in developing countries: The DIGNAR model. Economic Modelling, 52, 630-649. Available at: https://doi.org/10.1016/j.econmod.2015.10.007.

Nguyen, M. T., Renaud, F. G., Sebesvari, Z., \& Nguyen, D. C. (2019). Resilience of agricultural systems facing increased salinity intrusion in deltaic coastal areas of Vietnam. Ecology and Society, 24(4), 19. Available at: https://doi.org/10.5751/es11186-240419.

Thanh, N. X., \& Dapice, D. (2009). Vietnam's infrastructure constraints. Cambridge: United Nations Development Programme.

World Bank. (2010). Economics of adaptation to climate change. Washington DC: World Bank.

World Bank. (2011). Climate-resilient development in Vietnam: Strategic directions for the World Bank", sustainable development department. Washington DC: World Bank.

Views and opinions expressed in this article are the views and opinions of the author(s), Asian Journal of Economic Modelling shall not be responsible or answerable for any loss, damage or liability etc. caused in relation to/arising out of the use of the content. 